\title{
INTEGRATION CHALLENGES OF MEDIA POLICY IN BOSNIA AND HERZEGOVINA
}

\begin{abstract}
In the process of political transition of the Western Balkan countries, the non-EU countries in particular, the reform of communication systems occupies one of the primary places within the implementation of economic, cultural, political and integration processes of each country. Communication research that seeks to define the dilemmas of the current communication situation in Bosnia and Herzegovina, as a determining framework of the media system, includes many socio-political factors conditioned by structural changes within the society of Bosnia and Herzegovina in the last 25 years. The complete cultural and political deconstruction of the Bosnian society at the end of the twentieth and the beginning of the twenty-first century destabilized the internal organization of the political, cultural and economic system, especially in the domain of public communication and organization of the media subsystem. Apart from the numerous current challenges, the development of a unified media policy in Bosnia and Herzegovina and the establishment of a public media system in accordance with the requirements of the European Union and the interests of all citizens, are among the key issues that state institutions are facing at the moment. This paper primarily deals with the analysis of the European Commission's annual reports on Bosnia and Herzegovina's progress in the process of implementing reforms in the media policy sector and based on these annual reports it suggests the key factors for future national media policy definition. The goal is to establish a national media policy and reform the communication system in a broader context as a political, cultural and economic issue, i.e., as an institutionally agreed path for political compromise, integration of society and definition of collective identities.
\end{abstract}

Keywords: integration, media, politics, transition, identity

\section{Introduction}

General research on public communication in Bosnia and Herzegovina, as well as those concerning the current organization model of the media system, takes place in a complex cultural and historical context in which modern public and commercial media in Bosnia and Herzegovina have developed. Therefore, we can say that in the process of defining the national media policy of Bosnia and Herzegovina, i.e., its

\footnotetext{
${ }^{1}$ Received August 2021 / Accepted September 2021

2 email: mirza.mehmedovic@fulbrightmail.org
} 
adjustment to European principles, all specific factors that limit the development of the media must be taken into account, especially the establishment of a unique and transparent model of the public broadcasting system.

When we talk about the historical factors that influenced the current situation in the B-H media system, it is necessary to pay special attention to the end of the twentieth century, i.e., the breakup of the former Yugoslavia and interethnic conflicts in Bosnia and Herzegovina. The beginning of the 1990s meant the complete deconstruction of the prior social norms for Bosnia and Herzegovina, the collapse of the political system and the establishment of new models of public communication, which served the newly established political and military centers. Similar changes have taken place in other territories of the former Yugoslavia, where war conflicts and changes in the political system have brought about a complete reorganization of the media and the disintegration of the media market, both in engaging human and technical resources and shifting political and economic influence on the media. These changes have largely affected the current organization of the media system and resulted in the challenging application of European principles in the process of developing stable public media. However, the fact that the war conflicts affected the neighboring Yugoslav republics to a lesser extent and that social changes in these countries were marked by a milder migration and ethnic divisions, led to a faster political transition and stabilization of the media system than in the case of Bosnia and Herzegovina.

The communication changes that took place during the 1990s focused on the deconstruction of public media in the former socialist Yugoslavia, which until the end of the 1980s functioned as a state service within the chain of public communication established to preserve the political order and social relations. The ownership issues, more precisely the relationship between the state and the media in the socialist selfgoverning model and the relationship between private capital and the public interest in free markets, are burning communication dilemmas, especially for countries in transition between the two models. In addition to questioning the transparency of certain stages in the deconstruction of the socialist concept of mass media, an important factor in the process of defining new national media policies is the process of changing the perception of the role of the media in involving citizens in political flows. The transformation from representing the collective interest through the state mechanism of control over the media system to the stratification of public interests and strengthening the individual attitude of citizens towards current political processes is a major obstacle to taking on democratic roles in defining national media policies. Thus, Stjepan Malović, analyzing the transition of the Croatian media system, wrote in 2007: "Even seventeen years after the fall of the socialist self-governing society, we cannot rationally accept or apply some general categories of the free market" (Malović, 2007: 54).

At the end of the 1980s and the beginning of the 1990s, that is, with the growth of new national political movements, there was a stratification of the homogeneous communication system and the extremely pronounced efforts of political centers to control media resources in the newly formed republics. In this process, the former 
unified communication space was divided and all available media resources were mobilized for the purpose of public advocacy of national ideologies and political divisions in the former Yugoslav republics.

In addition to this communication turn, which preceded the armed conflicts in Bosnia and Herzegovina, it is important to analyze other factors that decisively guided the development of public media in the newly formed republics. It is extremely important to record other social movements, i.e., historical features in which the roots of modern communication stagnation on the territory of Bosnia and Herzegovina lie. Both throughout history and today, Bosnia and Herzegovina is by far the most limited by various cultural, ethnic, economic and political relations that are reflected in the definition of a unified media policy and progress in establishing a unified public media service. Armed conflicts, the emergence of new national ideologies and huge migrations of the population inside and outside the borders of Bosnia and Herzegovina, conditioned the establishment of a new political structure of the country, as well as the establishment of new territorial and political units. The new political organization, defined by the war conflicts that ended in the mid1990s, represents the most significant obstacle to the process of overall society integration, defining the common interests of all citizens, and especially the practical implementation of political reforms.

Even in historiographical works dealing with the contemporary history of Bosnia and Herzegovina, the instrumentalization of the media is cited as one of the key frameworks for establishing new communication habits of the audience and verifying ethnic divisions. Thus, the British historian Noel Malcolm separates the political effects of ethnic cleansing and the role of the media in broadcasting: "The fact that there was no mass return of refugees to their homes, which over time was only 'sealed' by many selling their pre-war houses to new tenants, consolidated the effects of ethnic cleansing. The fact that education and the media were under the control of the entity authorities contributed to the distorted portrayal of recent history becoming widely accepted among the population of the Republic of Srpska" (Malcolm, 2011: 27).

Similar observations on the role of the media in the war during the 1990s can be found in the reports of the United Nations Special Rapporteur Tadeusz Mazowiecki, which state the following as a general impression of the situation in the media system: "The media of the former Yugoslavia are one of the most important means of propagating the military conflict in that region. It is believed that the media were even active participants in the conflict itself and that they themselves encouraged or provoked many violations of human rights and international human law" (Mazowiecki, 2007: 403).

The mentioned media analysis, which Mazowiecki conducted during the 1990s and published its results in the form of summary reports, can be accepted from the communicology aspect only as a historiographical record of the specifics of the Bosnian communication situation at the end of the twentieth century. Similarly, Kurtić observes specific reports, in which he does not see a significant contribution to communication research related to the propaganda role of the media and adds: 
"The history of civilization is full of similar examples of the transformation of a peacetime, even the media subsystem of democratic societies, into the war-propaganda subsystem of a militarized society. In that sense, communicology research cannot count on new scientific information, even at the level of war propaganda techniques" (Kurtić, 2011: 99).

\section{Media policy issues}

The aim of this paper is not to explain the causes or ways of political instrumentalization of the media in Bosnia and Herzegovina at the end of the twentieth century, but to identify their reflections on the modern public communication system and current perspectives/foundations on which to build an acceptable European media policy. One of the key preconditions for defining a unified media policy in Bosnia and Herzegovina is the harmonization of all complex (heterogeneous) cultural characteristics, as well as specific features of the modern communication situation, aiming to reach a model that would meet the specific needs of citizens and standards applied by the European Union.

In attempts to fulfill this, but also all other conditions, it is important to primarily define the very concept of media policy, i.e., the etymological origin and interpretation of the concept in the current social context in which the position of media and communication in general is considered. In addition, having in mind the specific problems that characterize the current communication situation in Bosnia and Herzegovina, this paper seeks to update the definition of a unique model of media policy which is acceptable for the current socio-political system, able to adapt to modern media market and resist external pressures of political and economic centers.

After the deconstruction of the social order and the collapse of the internal structure of the media system of Bosnia and Herzegovina, the current communication dilemmas are mainly related to the (non) existence of relevant and operational institutions/organizations that would manage the process of defining media policy, i.e., the development of public communication. However, taking into account the already mentioned complexity of the current communication situation, this dilemma opens up a number of other related questions which need to be answered.

Which laws or professional regulations govern the media market, especially the public service broadcasting system? How is the regulation implemented in practice and how is the work and development of the media system monitored? To what extent have the communication (media) conditions prescribed by the European Union for potential member countries been met? What is the position of media policy in public discourse and in what way? To what extent do the existing media (primarily public) resources correspond to the information needs of citizens?

In order to offer answers to these questions, it is important to understand the term itself, but also the contemporary context of media policy, especially for countries undergoing radical changes in the political and social system, such as 
Bosnia and Herzegovina. In terms of content, the concept of media policy can be viewed as a continuous process of managing development and responding to changes in the public communication system, and we primarily refer to the process of adapting to technical-technological and socio-political changes in modern media and other subjects of public communication. The concept of media policy unites two extremely broad terms, the first being "media", which primarily refers to the mass media, i.e., channels of mass communication, and the second being "politics", which, as Milardović states, originates from the Greek words polis, politea, politic, politics:

- polis: city-state, city area, also a set of citizens that make up the city;

- politeia: state, constitution, political regime, republic, citizenship (in terms of law citizenship);

- politics: a neutral plural of politikos, political things, civil things, everything related to the state, constitution, political regime, republic, sovereignty;

- politics tehne: political art; (Milardović, 1996: 6).

Politics is basically the ability to manage public affairs and this ability is reflected in an adequate and timely response to social changes and sensitivity to the different interests of all participants in social (public) processes. Additionally, media policy is a phrase which implies the ability to manage the media, i.e., the public communication system and adequately respond to technical-technological, social and market changes, taking into account the interests and needs of all participants in public communication, such as governmental and non-governmental organizations, political parties, citizens and various social groups through the mass media.

\section{European Union and media policy}

Since its founding, the European Union has gone through various stages of political evolution with the aim of creating an ever-closer alliance among the peoples of Europe and establishing modern common institutions based on democratic decision-making of common interest to the member countries.

The historical continuity and political strengthening of the European Union are indicators that this alliance was constituted primarily on common economic interests, which led to the unification of markets, the introduction of a single customs system and a new currency. From a legal point of view, many competencies are still left to the governments of the member states, provided that they follow certain EU directives defined with the aim of strengthening the common market and interconnecting individual countries. The governments of the member states, as well as the countries aspiring to join the European Union, are left with the competence to adopt the media/communication regulations, which must be harmonized with the EU directives, defined through the decades of experience of European democracies and harmonized common communication interests. 
In the field of activities of the European Parliament and the Council of the European Union regarding the media policy of the European Union and in accordance with the proposals of the European Commission, the Directive on Audiovisual Media Services is especially important for the future development of the media system of Bosnia and Herzegovina and the public broadcasting sector. ${ }^{3}$ Although in the regulatory sense many competencies in the field of organization of audiovisual media services are left to the member states, the Directive encompasses elementary principles of media policy, both in the field of application of modern technologies and representation of cultural and democratic principles in public communication.

In this segment, it is particularly important to single out Recital 5 of the Directive, in which audiovisual services are treated as cultural services, which is particularly important in national public broadcasting systems and their basic principles: "Audiovisual media services are as much cultural services as economic services. Their growing importance for societies, democracy - in particular ensuring freedom of information, diversity of opinion and media pluralism - education and culture justifies the application of special rules to these services."

It is clear from the mentioned article that the European Union, taking into account the specific cultural characteristics of different societies, encourages the establishment of specific regulatory frameworks for audiovisual media services, with the aim of protecting pluralism and the role of the media in the democratization process.

Taking into account the stated social conditions in which the modern Bosnian media system is developing, the EU policy defined in this way focuses on future development in the competence of state institutions which are obliged to harmonize the provisions of future development of a common media system capable of ensuring pluralism and cultural diversity.

The Directive also suggests that the member states should take responsibility for preventing the creation of dominant positions between television programs, or in the information sector as a whole, as defined in Recital 8: "It is important that member states ensure that any conduct that could prove detrimental to the freedom of movement and trade in television programs, or that could promote the creation of dominant positions, would lead to restrictions on pluralism and freedom of television information and information sector in whole." These articles of the Directive basically offer elementary frameworks in which the future development policy of the B\&H media system should operate, both in the domain of satisfying specific cultural differences of the Bosnian society and in the domain of enabling the free flow of information as the foundation of a democratic political system.

On the other hand, in this part of the paper we must mention the mechanisms of cooperation between Bosnia and Herzegovina and the European Union, i.e., the role of the European Commission, as a body that constantly monitors Bosnia

\footnotetext{
${ }^{3}$ Directive 2010/13 / EU of the European Parliament and of the Council of 10 March 2010 on the coordination of certain provisions laid down by law, regulation or administrative action in Member States concerning the provision of audiovisual media services (Audiovisual Media Services Directive), Official Journal of the European Union (January 15 2010)
} 
and Herzegovina's progress in applying European principles. The Commission's responsibilities are set out in the regular periodic progress reports which are mainly presented annually.

Having in mind the audiovisual recommendations of the European Union, based on democratic values and experiences of member states, as well as defined mechanisms of Bosnia and Herzegovina's relations with EU institutions in the process of accession and application of European communication standards, we can say that Bosnia and Herzegovina's institutions must respond the following challenges:

1. harmonization of the normative/legal framework for the functioning of audiovisual media with the directives of the European Union

2. harmonization of specific cultural and traditional values that must be represented in the operation and production of audiovisual media (commercial and public)

3. development of information and communication technologies in accordance with modern market requirements, as a prerequisite for networking with the European media system

If we look at the above development elements of the B\&H media policy, which are the essence of approximation to the prescribed EU directives, it is clear that they also represent the main challenges of the process of stabilization and integration of the public and commercial media system of Bosnia and Herzegovina.

\section{Monitoring of reforms in Bosnia and Herzegovina}

Although the European Union leaves the focus of defining media policy to the national governments of the member states, the European Commission provides direct assessments of the internal stability of the political system and related subsystems, including the public communications sector, in periodic progress reports on Bosnia and Herzegovina. The parts of the European Commission's report dealing with the public communication system mainly cover the activities of state institutions and the application of modern principles of management and technical training ${ }^{4}$; from the perspective of EU enlargement, the contents of the report can be seen as political qualifications for the accession process.

Although the European Commission monitors the reform of the national communication system in Bosnia and Herzegovina as part of the monitoring of the overall situation in the country, the conclusions and suggestions of the European Commission show that the European Union requires internal political stability, defined national cultural identity and an autonomous public communication system based on the application of modern technologies and the preservation of cultural property.

Given the specific cultural and historical context that has conditioned the current characteristics of Bosnia and Herzegovina's national identity, it is understandable

\footnotetext{
${ }^{4}$ Currently available reports of the European Commission on the progress of Bosnia and Herzegovina are in the period from 2010 to 2018.
} 
why the European Union views Bosnia and Herzegovina as a specific region for future enlargement. The available annual reports of the European Commission on progress in Bosnia and Herzegovina show a gradation of attitudes from simple notes of the overall situation, to criticisms of the stagnation of reforms and proposed measures. From shifting the positions of the European Union, we can draw conclusions about the doubts of international institutions about the need to be involved in resolving current political and cultural dilemmas of the B\&H society, although, judging by the report, the current dynamics of reforms is not in line with the EU expectations.

Through the analysis of the annual progress reports of Bosnia and Herzegovina, published by the European Commission from 2010 to the end of 2018, there is an obvious continuity in the negative elements that slow down the process of reforming public broadcasting and approximation to European media policy principles. Also, the reports show an uneven level of interest of the European Commission for a detailed analysis of the situation in certain sectors, which could ultimately result in a more complete picture of Bosnia and Herzegovina's progress, or even concrete proposals of European institutions to overcome certain issues. By comparing these sections of the annual reports, it is possible to identify several key elements that need to be overcome in order to make progress in the reform of the public broadcasting sector in Bosnia and Herzegovina:

1. Harmonization of entity laws on public broadcasting with the state Law on Public Broadcasting System of Bosnia and Herzegovina

2. Adoption of legal frameworks that would increase the level of RTV fee collection and provide a stable source of public funding for public broadcasters

3. Establishment of the Corporation of Public Broadcasting Services

4. Ensuring the independence of the Communications Regulatory Agency of Bosnia and Herzegovina

5. Completion of the process of digitalization of radio and television broadcasting

6. Digital connection of production centers of the public radio and television system

7. Strengthening the administrative capacity of the Ministry of Transport and Communications of Bosnia and Herzegovina

8. Harmonization of the state Law on Electronic Communications of Bosnia and Herzegovina with modern European regulatory frameworks

\section{Conclusions}

Having in mind the current domestic and international political relations that directly define the dynamics of social, cultural and economic reforms needed for stabilization and accession of Bosnia and Herzegovina to Euro-Atlantic integration, the reorganization of the public communication system is positioned at the very top of EU demands. However, the reform of the public broadcasting sector in Bosnia and Herzegovina has not seen adequate progress in the past ten years, i.e., in a period 
in which this issue has become the interest of domestic political interventions and international analysis of Bosnia and Herzegovina's progress.

Contrary to the expectations of international reform monitoring bodies, the public service broadcasting system still reflects the country's complex political system, based on the basic principles of the Dayton Accords, which partly defined cultural relations and collective identities as subjects of political processes. Although the reports confirm the stagnation of the reform and integration of the public broadcasting system in Bosnia and Herzegovina, key shortcomings of the current organization have been identified, as well as potential foundations for future development and approximation to the European Union standards. Within the complex cultural and political changes that modern Bosnian society is going through, destabilizing elements of the communication system have been recorded, the strengthening of which can lead to the integration of management structures while satisfying the various communication interests of all citizens of Bosnia and Herzegovina.

The annual reports of the European Commission, which present the progress of Bosnia and Herzegovina in implementing reforms in the public broadcasting sector, show that primary attention is paid to the need to harmonize the entities with the state Law on Public Broadcasting System. Practice shows that the legal framework ensures complete autonomy of individual parts of the public broadcasting system, i.e., special management and editorial policy bodies within three public broadcasters (two entity broadcasters and one state broadcaster).

The missing regulatory framework that would regulate the overall electronic media market in Bosnia and Herzegovina is certainly the state law on electronic media, which would determine the conditions under which licenses are granted and allow the distribution of electronic media programs to users in Bosnia and Herzegovina. Certain parts of the reports confirm that Bosnia and Herzegovina still does not have defined mechanisms for monitoring the establishment and operation of electronic media, as well as an adequate model for protecting the domestic market from the continuous penetration of foreign media.

\section{References}

Annual reports of the European Commission on the progress of Bosnia and Herzegovina in the period from 2010 to 2018

Directive 2010/13 / EU of the European Parliament and of the Council of 10 March 2010 on the coordination of certain provisions laid down by law, regulation or administrative action in Member States concerning the provision of audiovisual media services (Audiovisual Media Services Directive), Official Journal of the European Union (January 15 2010)

(https://eur-lex.europa.eu/LexUriServ/LexUriServ.do?uri=OJ:L:2010:095:0001:0024: $E N: P D F)$ 
Kurtić, N. (2011). Communication examinations, Bosnian word

Malcolm, N. (2011). Bosnia: A Short History, Buybook

Malović, S. (2007). Media and Society, ICEJ

Mazowiecki, T. (2007). Reports 1992 - 1995, University of Tuzla

Milardović, A (1996). Introduction to political science, PAN-LIBER

\title{
INTEGRACIJSKI IZAZOVI MEDIJSKE POLITIKE U BOSNI I HERCEGOVINI
}

\begin{abstract}
Abstrakt: U procesu političke tranzicije zemalja Zapadnog Balkana, prvenstveno zemalja koje još uvijek nisu članice Europske unije, reforma komunikacijskih sistema zauzima jedno od primarnih mjesta unutar provođenja ekonomskih, kulturnih, političkih i integracijskih procesa svake zemlje pojedinačno. Komunikološka istraživanja koja nastoje definisati dileme aktuelne bosanskohercegovačke komunikacijske situacije, kao determinirajućeg okvira medijskog sistema, uključuju mnoge društveno-političke faktore uslovljene strukturalnim promjenama unutar bosanskohercegovačkog društva u posljednjih 25 godina. Potpuna kulturna i politička dekonstrukcija bosanskohercegovačkog društva na kraju dvadesetog i početku dvadeset prvog stoljeća destabilizovala je unutrašnju organizaciju političkog, kulturnog i ekonomskog sistema, posebno u domenu javne komunikacije i organizacije medijskog podsistema. Među mnogim aktuelnim izazovima, razvoj jedinstvene medijske politike na području Bosne $i$ Hercegovine, te uspostava javnog medijskog sistema u skladu sa zahtjevima Europske unije $i$ interesima svih građana, spadaju u ključna pitanja sa kojima se suočavaju državne institucije. Ovaj rad se primarno bavi analizom sadržaja godišnjih izvještaja Europske komisije o napretku Bosne i Hercegovine u procesu provođenja reformi u sektoru medijske politike, te na osnovu ključnih elemenata godišnjih izvještaja sugeriše ključne faktore budućeg definisanja nacionalne medijske politike. Cilj je pozicionirati pitanje uspostave nacionalne medijske politike i reforme komunikacijskog sistema u širem kontekstu, kao političko, kulturno i ekonomsko pitanje, odnosno kao institucionalno usaglašen put za politički kompromis, integraciju društva i definisanje kolektivnih identiteta.
\end{abstract}

Ključne riječi: integracija, mediji, politika, tranzicija, identitet 